\title{
Occurrence and molecular characterization of Cucumber green mottle mosaic virus in cucurbit crops of KPK, Pakistan
}

\author{
Asad Ali ${ }^{1,2}$, Adil Hussain ${ }^{2}$, Musharaf Ahmad ${ }^{2}$ \\ ${ }^{1}$ Laboratory of Plant Pathology, Faculty of Agriculture, Utsunomiya University, Mine Campus, Japan. \\ ${ }^{2}$ Department of Plant Pathology, The University of Agriculture, Peshawar, Pakistan.
}

Submitted: August 9, 2013; Approved: April 17, 2014.

\begin{abstract}
Field survey of the cucurbit crops revealed a high incidence of Cucumber green mottle mosaic virus (CGMMV) in Khyber Pakhtunkhwa Province (KPK), Pakistan. Among the seven districts surveyed, average percent incidence of CGMMV was recorded up to $58.1 \%$ in district Nowshera, followed by $51.1 \%$ in district Charsada, $40.5 \%$ in district Swabi and 37.3\% in district Mardan. In Swat and Dir districts average incidence CGMMV was recorded upto $31.2 \%$ and $29.4 \%$, respectively. Among the different crops highest incidence in plain areas of KPK was recorded in bottle gourd (59.3\%) followed by $56.3 \%$ in Squash, $54.5 \%$ in Pumpkin, $45.5 \%$ in Melon, $41.7 \%$ in Cucumber and $29.9 \%$ in Sponge gourd. In Northern hilly areas highest incidence of CGMMV $(52.9 \%)$ was observed in pumpkin, followed by $49.6 \%$ in bottle gourd, $47.3 \%$ in squash, $45.1 \%$ in Melon $42.3 \%$ in cucumber and $41.6 \%$ in sponge gourd. Little variability was observed in the coat protein amino acid sequence identities of CGMMV Pakistan isolate, when compared with other reported isolates.
\end{abstract}

Key words: cucurbit, CGMMV, incidence, tobamovirus, Pakistan.

\section{Introduction}

Plants of the family Cucurcbitaceae, including many edible and non-edible species, are native in most countries of the world, especially in the tropics and in areas with relatively warm temperature. Cucurbit fruits have yellow, white or orange flesh, which is rich in carotenoids, the compounds humans need to make vitamin A, and the visual pigment rhodopsin. Cucurbit crops, including summer squash (Cucurbita pepo), bottle gourd (Lagenaria siceraria), cucumber (Cucumis sativus), sponge gourd (Luffa acutangula), bitter gourd (Momordica charantia) and snake/serpent gourd (Cucumis melo var. flexuosus), produced throughout Pakistan including the Khyber Pakhtunkhwa (KPK) and are regarded as important summer and winter vegetables.

In KPK cucurbits are grown on 3140 ha (does not include the figures for lufa, long-melon and cucumber at provincial level, as these were not available) with an annual estimated production of 29544 tons, while in Pakistan cucurbit occupies an area of 28600 ha with a total annual pro- duction of 261,306 tons (MINFAL, 2008). The average yield of such crops (approximately 9 tons/ha) in the region is quite low. A number of biotic and abiotic factors are responsible for this low yield. The cultural practices adapted by the growers, conducive environmental conditions for disease epidemic development, lack of awareness of growers both about viral disease epidemiology and the precautions required for control and the use of uncertified seeds are the major factors that result in high incidence of viral diseases. High population of weeds also plays an important role in virus epidemiology and is a common problem in vegetable growing areas of KPK.

Cucurbit viral diseases are a worldwide problem and induce major economic losses in commercial cucurbit production around the world (Lovisolo, 1980). Specially the vector transmitted viruses that may causes losses as high as 100\% (Ullman et al., 1991). Almost 35 different viruses have been isolated from Cucurbitaceae (Provvidenti, 1996). In Pakistan cucurbit viruses are quite prevalent in the different cucurbit crops of KPK (Ali et al., 2004; Khalid and Ahmad, 1997). 
Cucumber green mottle mosaic virus (CGMMV) is member of Tobamovirus genus, and is commonly reported in different cucurbit crops throughout the world (Nameth et al., 1986; Ullman et al., 1991; Desbiez and Lecoq, 1997; Choi, 2001; Lecoq et al., 2001; 2003; Ali et al., 2004). The virus is also seed transmitted in different cucurbits and is usually present on the surface of the seed as seed contaminant. The very high stable genome coupled with transmission through seeds and contact makes this virus a big menace causing heavy losses across the world wherever cucurbits are grown. Presence of the inoculum right from the beginning of the crop growth results in a very high infection/incidence level and usually it is very difficult for plants to resist infection under such circumstances (Coutts and Jones, 2005). According to a preliminary pilot study CGMMV infection was high in cucurbit crops of KPK (Ali et al., 2004). The present study is first ever effort to determine the detailed incidence and status of CGMMV in different cucurbit crops as well as different agro ecological zones of KPK, to characterize the virus at molecular level and to know the phyhlogenetic status of the Pakistani isolates.

\section{Material and Methods}

\section{Field survey}

A total of 22 fields in seven districts of the KPK viz; District Peshawar (Tarnab, Budni and Taru), District Nowshera (Jehangira, Nowshera, Pirsabaq), District Mardan (Shelgazi Baba Mumtaz Abad, Takhtbhai), District Swabi (Kalu Khan, Shewi Adda, Tordheri,), District Charsada (Sheikhabad, Umerzai, Serdheri), District Swat (Manyar, Bahrain, Kaidam Kalam, Batkhela) and District Dir (Gulabad, Talash, Timergarah, Chakdara) were surveyed to find out the incidence and distribution of CGMMV in Pakistan for two consecutive years (20072009) collecting randomly a total of 35 samples from each field. Major crops surveyed for the collection of samples were bottle gourd (Lagenaria siceraria), sponge gourd (Lufa acutangula), cucumber (Cucumis sativus), pumpkin (Cucurbita pepo), squash (Cucurbita muschata) musk melon (Cucumis melo) etc. The collected samples were brought to the plant virology laboratory and stored at $-80{ }^{\circ} \mathrm{C}$ till further processing.

\section{Disease incidence}

All the collected plant samples were tested for the presence of Cucumber green mottle mosaic virus (CGMMV) using DAS-ELISA [Double Antibody Sandwiched-Enzyme Linked Immunosorbent Assay (Clark and Adams, 1977). Commercial kits from (Agdia, USA) were used for analysis of the samples. All the buffers, coating antibodies and conjugated antibodies were diluted as per the recommendations of the manufacturer. Following procedure was used to assay the samples. $100 \mu \mathrm{L}$ of the antibod- ies, diluted in coating buffer $(1: 2000 \mathrm{v} / \mathrm{v})$, were coated in each well of the ELISA plates and the plates were incubated at $37{ }^{\circ} \mathrm{C}$ for $2 \mathrm{~h}$. After incubation the plates were washed three times with the help of washing buffer. -The collected samples were crushed thoroughly in the extraction buffer (1:5 w/v) and $100 \mu \mathrm{L}$ of the sap was applied to the wells. The plates were incubated at $4{ }^{\circ} \mathrm{C}$ overnight and were washed thrice again with the help of washing buffer. After washing, $100 \mu \mathrm{L}$ of the diluted conjugate antibodies $(1: 1000 \mathrm{v} / \mathrm{v})$ were applied to the wells and the plates were incubated at $37{ }^{\circ} \mathrm{C}$ for $1 \mathrm{~h}$. Washing was repeated again three times using washing buffer and finally $100 \mu \mathrm{L}$ of substrate (p-nitro-phenyl phosphate @ $1 \mathrm{mg} / \mathrm{mL}$ ) were applied to each well. The plates were incubated at about $25^{\circ} \mathrm{C}$ (or room temperature) in dark. Data were taken after $30 \mathrm{~min}$ and after $60 \mathrm{~min}$.

Disease incidence was calculated using the following formula;

$\%$ Disease incidence $=\frac{I p}{N p} \times 100$

where $I p=$ number of infected plants and $N p=$ total number of plants.

\section{RT-PCR amplification and sequence analysis of the coat protein gene of CGMMV}

The cDNA of the selected positive samples was synthesized using iScript cDNA synthesis kit (Bio-Rad, USA) according to the manufacturer's instructions with 3'-end virus-specific primer. CGMMV RNA was isolated by simple direct tube (SDT) method (Suehiro et al., 2005) by crushing the symptomatic leaf $(0.1 \mathrm{~g})$ in $1 \mathrm{~mL}$ of PBST (PBS $+1 \%$, Tween 20) pH 7.4. $50 \mu \mathrm{L}$ sap was transferred to a $1.5 \mathrm{~mL}$ microfuge tube and incubated at room temperature for $15 \mathrm{~min}$. The tubes were then washed twice with PBST and $30 \mu \mathrm{L}$ of nuclease free water was added into the tube through pipetting. The contents were placed on hot water bath at $95{ }^{\circ} \mathrm{C}$ for $3 \mathrm{~min}$. After heating, $8 \mu \mathrm{L}$ were transferred to a PCR tube with $0.5 \mu \mathrm{L}$ reverse transcriptase enzyme, $2 \mu \mathrm{L}$ of $5 \mathrm{x}$ reaction mix and $0.5 \mu \mathrm{L} 3$ ' specific primer, to make a total of $11 \mu \mathrm{L}$ reverse transcription reaction mixture. cDNA synthesis was performed in three steps including primer annealing at $25^{\circ} \mathrm{C}$ for $5 \mathrm{~min}$ followed by extension at $42^{\circ} \mathrm{C}$ for $30 \mathrm{~min}$ and finally treatment of $85^{\circ} \mathrm{C}$ for $5 \mathrm{~min}$. This cDNA was then used to amplify the coat protein region of CGMMV, using Super-Hot master mix (Bioron, Germany) in $50 \mu \mathrm{L}$ PCR mixture containing $1 \mu \mathrm{L}$ cDNA, $22 \mu \mathrm{L}$ nuclease free water, $1 \mu \mathrm{L}(25 \mathrm{pmol})$ each of the CP-F (GATGCATTCTGTTGCAGAGG) and CP-R (TCAACCTCACACACGTAAGA GG) virus specific primers and $25 \mu \mathrm{L}$ of $2 \mathrm{x}$ PCR Super-Hot master mix (1 unit Taq DNA polymerase, $32 \mathrm{mM}\left(\mathrm{NH}_{4}\right)_{2} \mathrm{SO}_{4}, 130 \mathrm{mM}$ Tris HCL with $\mathrm{pH} 8.8,0.02 \%$ Tween-20, $3 \mathrm{mM} \mathrm{MgCl}_{2}$ and $0.4 \mathrm{mM}$ each of the dNTPs). After the initial denaturation step at $94^{\circ} \mathrm{C}$ for $2 \mathrm{~min}, \mathrm{PCR}$ was performed for 35 cycles, 
each at $94{ }^{\circ} \mathrm{C}$ for $1 \mathrm{~min}, 55^{\circ} \mathrm{C}$ for $30 \mathrm{~s}$ and $72{ }^{\circ} \mathrm{C}$ for $1 \mathrm{~min}$, followed by a final extension step at $72{ }^{\circ} \mathrm{C}$ for 1 min using MJmini Thermal Cycler, Bio RAD, USA. The (RT) PCR products were separated in 2\% agarose gel electrophoresis and detected by ethidium bromide staining under UV light in UVITEC, Gel Doc, UK.

Following PCR amplification, the RT-PCR products of three isolates from different divisions were electroeluted from the gel using standard procedures (Sambrook and Russell, 2001) and cloned into pUC19 cloning vector for transformation. Competent cells of Escherichia coli strain NEB 5- $\alpha$ (New England biolabs) were transformed with the cloned DNA according to the recommendations of the manufactures. Standard alkali lyses method was used to isolate plasmid DNA (Sambrook and Russell, 2001). Plasmids with the desired DNA insert were selected and sequenced using ABI sequencer. The sequence was analyzed to determine the phylogenetic status of Pakistani Isolate.

Alignment of amino acid (aa) and nucleotide (nt) sequences, representing the coat protein (CP) region of CGMMV-Pak with sequences reported in the data bank (Table 1) were constructed using protein and DNA alignment program in GENETYX Win Version 5.1 (Software Development, Tokyo, Japan). The deduced aa and nt sequences were compared with the sequences reported in the DNA database and the phylogenetic relationship was established using the CLUSTAL-W program (Thompson et al., 1994), by the Neighbor Joining Method. The phylogenetic trees were viewed in Treeview (win32) 1.6.6 program. The amino acid sequence of the Pakistani isolate was compared with the sequences reported elsewhere in the world (Table 1).

\section{Results and discussion}

Field surveys of the cucurbit crops revealed a high incidence of leaf mosaic, mottling, chlorosis and deformation in KPK, Pakistan. The newly growing apical leaves were small with very conspicuous symptoms. $L$. siceraria plants mostly exhibited mosaic symptoms. Interveinal chlorosis and severe mosaic symptoms were observed on C. sativus. Squash plants were also showing severe mosaic, mottle, deformation and filiformism. In some of the fields with severe infection leaves were having shoe-string appearance. The prevalence of such symptoms in cucurbit crops have already been reported by Ali et al. (2004); Khalid and Ahmed (1997) and Malik et al. (2006).

Among the seven districts surveyed, the highest incidence of CGMMV was recorded in Charsada (57.05\%) during the final survey of the first season as compared to $29.3 \%$ incidence at district Swabi during the earlier survey, the same season. Farmers cultivated different cucurbits in the same fields. Bottle gourd, sponge gourd and squash were often seen cultivated in the same field thereby increasing the crop density making virus transmission more easy
Table 1 - List of sequences used in the phylogenetic analysis of CGMMV.

\begin{tabular}{lcc}
\hline Virus acronym/strain & Geographic region & Accession Number \\
\hline TMV (Out group) & USA & NC 001367 \\
Strain C & Japan & AB015144 \\
Yodo strain & Japan & AB015145 \\
WM strain & Japan & AB015146 \\
SH strain & Japan & D12505 \\
SH strain & Japan & BAA02071 \\
Strain NS & Korea & AJ243831 \\
NS strain & Korea & CAB52287 \\
WM strain & Korea & AF225984 \\
Strain Y & Korea & AJ245440 \\
Indian & India & EU366912 \\
India & India (Rajasthan) & DQ767636 \\
Chinese & China & DQ997778 \\
Russian & Russia & EF521882 \\
GR7 & Greece & AJ459423 \\
France & France & CAD22087 \\
Indonesian & Indonesia & AB194531 \\
\hline
\end{tabular}

and quick. Also the cucurbit season lasted a little longer in district Charsada compared to district Swabi which might be responsible for the high incidence. In the early survey of the first season incidence was in the range of $12.50 \%$ (cucumber) to $37.50 \%$ (pumpkin) which increased up to $66.66 \%$ (bottle gourd). The least percent infection was found in district Mardan (46.52\%). CGMMV infection during the first survey of the second season ranged from $6.6 \%$ in cucumber to $36.6 \%$ in squash. Highest average percent incidence of $25.6 \%$ was observed in district Charsada followed by $27.4 \%$ in district Nowshera, $23.6 \%$ in Peshawar, $18 \%$ in district Swabi and $15.9 \%$ in district Mardan. However, during the late survey of the second season average percent incidence of CGMMV increased up to $58.1 \%$ district Nowshera, followed by $51.1 \%$ in district Charsada, $40.5 \%$ in district Swabi and $37.3 \%$ in district Mardan (Table 2).

In Swat and Dir districts the highest incidence of CGMMV during the first season was observed in district Swat where average percent incidence of $31.23 \%$ was recorded. In district Dir virus incidence was recorded as 29.37\%. Percent incidence in district Swat ranged from $13.3 \%$ in cucumber to $56.25 \%$ in bottle gourd, while in district Dir percent incidence in different crops ranged from $10 \%$ to $53.33 \%$ in bottle gourd crop during the first season of crop growth. However, during the second season highest average percent incidence $(36.20 \%)$ was recorded in district Swat and 27.20\% in district Dir (Table 3)

Average percent incidence in the plain areas of KPK was the highest in Pumpkin (35.65\%) during the first survey of the first season, followed by $25.80 \%$ in Bottle gourd, 
Table 2 - Percent incidence of CGMMV in the plain areas of KPK.

\begin{tabular}{|c|c|c|c|c|}
\hline \multirow[t]{2}{*}{ Districts surveyed } & \multicolumn{2}{|c|}{ 1st year } & \multicolumn{2}{|c|}{ 2nd year } \\
\hline & $1^{\text {st }}$ survey & $2^{\text {nd }}$ survey & 1st survey & $2^{\text {nd }}$ survey \\
\hline District Peshawar Tarnab (Squash) & 25 & 65.6 & 26.6 & 56.25 \\
\hline Taru (Squash) & 16.6 & 56.6 & 19.4 & 41.4 \\
\hline Budni (Bottle gourd) & 23.3 & 53.14 & 21.87 & 48.2 \\
\hline Taru (Sponge gourd) & 13.3 & 26.6 & 26.6 & 30.5 \\
\hline Average & 19.55 & 50.49 & 23.6 & 44.1 \\
\hline District Nowshera Jehangira (Squash) & 13.3 & 50 & 36.6 & 66.6 \\
\hline Pirsabaq (Bottle gourd) & 26.6 & 66.66 & 23.3 & 56.6 \\
\hline Nowshera (Cucumber) & 12.5 & 33.33 & 16.6 & 46.6 \\
\hline Azakhel (Pumpkin) & - & - & 33.3 & 62.5 \\
\hline Average & 17.47 & 49.99 & 27.4 & 58.1 \\
\hline District Mardan Takhtbahi (Bottle gourd) & 33.3 & 53.14 & 25 & 40.5 \\
\hline Katlang (Sponge gourd) & - & - & 12.5 & 41.4 \\
\hline Takhtbahi (Sponge gourd)) & 16.6 & 33.3 & - & - \\
\hline Mumtaz Abad (Squash) & 23.3 & 53.12 & 19.6 & 45.2 \\
\hline Sher Garh (Cucumber) & - & - & 6.6 & 22.1 \\
\hline Average & 24.4 & 46.52 & 15.9 & 37.3 \\
\hline District Charsada Serdheri (Bottle gourd) & 20 & 64.5 & 26.6 & 53.3 \\
\hline Sheikhabad (M. Melon) & 33.3 & 56.66 & 23.3 & 45.4 \\
\hline Umerzai (Cucumber) & 23.3 & 50 & 33.3 & 62.5 \\
\hline QaziKhel Jadid (Sponge gourd) & - & - & 19.4 & 43.3 \\
\hline Average & 25.53 & 57.05 & 25.6 & 51.1 \\
\hline District Swabi Tordher (M.Melon) & 16.6 & 34.37 & 19.4 & 44.9 \\
\hline Kernal Sher Keli (Pumpkin) & 37.5 & 65.62 & 13.3 & 27.4 \\
\hline Kalu Khan (Pumpkin) & 33.8 & 43.3 & 19.4 & 43.3 \\
\hline Zaida (Sponge gourd) & - & - & 20 & 46.3 \\
\hline Average & 29.3 & 47.76 & 18 & 40.5 \\
\hline
\end{tabular}

Table 3 - Percent incidence of CGMMV in the hilly areas of KPK.

\begin{tabular}{|c|c|c|c|}
\hline \multirow[b]{2}{*}{ District Swat } & \multicolumn{2}{|l|}{$1^{\text {st }}$ year } & \multirow[t]{2}{*}{$2^{\text {nd }}$ year } \\
\hline & & & \\
\hline Kalam (Cucumber) & 33.3 & Kaidam (Pumpkin) & 36.4 \\
\hline Kalam (Pumpkin) & 30 & Ashoran (Cucumber) & 32.3 \\
\hline Bahrain (Cucumber) & 13.3 & Laikot (Lagenaria) & 33.3 \\
\hline Batkhela (Lagenaria) & 56.25 & Batkhela (Luffa) & 38.7 \\
\hline Manyar-Swat (Pumpkin) & 23.3 & Bahrain (Cucumber) & 40.1 \\
\hline Average & $31.23^{*}$ & Average & 36.20 \\
\hline \multicolumn{4}{|l|}{ District Dir } \\
\hline Talash (Pumpkin) & 34.37 & Talash (Cucumber) & 38.3 \\
\hline Chakdara (Lagenaria) & 10 & Chakdara (M. Melon) & 36.4 \\
\hline Talash (Lagenaria) & 12.5 & Gulabad (Luffa) & 28.3 \\
\hline Temergarah (Lagenaria) & 53.33 & Temergarah (Squash) & 15.3 \\
\hline Gul Abad (Luffa) & 36.66 & Chakdara (Lagenaria) & 17.4 \\
\hline Average & 29.37 & Average & 27.20 \\
\hline
\end{tabular}

$24.95 \%$ in Melon, $19.55 \%$ in Squash, 17.90\% in Cucumber and $14.95 \%$ in bottle gourd (Table 4). Percent incidence of CGMMV increased rapidly upto $59.34 \%$ in Bottle gourd, $56.33 \%$ in Squash, 54.46 in Pumpkin, 45.51 in Melon, 41.65 in Cucumber and 29.95 in Sponge gourd during the second survey (Table 4). During the second season highest incidence of CGMMV (52.9\%) was observed in pumpkin, followed by $49.6 \%$ in bottle gourd, $47.3 \%$ in squash, $45.1 \%$ in Melon $42.3 \%$ in cucumber and $41.6 \%$ in sponge gourd (Table 4).

In the northern areas of KPK the highest average percent infection during the first season, was recorded in bottle gourd where $41.66 \%$ incidence was recorded, followed by $37.1 \%$ in pumpkin, $36.66 \%$ in cucumber and $26.66 \%$ in sponge gourd. However, during the second year highest incidence $(36.9 \%)$ was recorded in cucumber, followed by $36.4 \%$ in pumpkin, $33.5 \%$ in sponge gourd, $25.4 \%$ in bottle gourd and $15.3 \%$ squash (Table 5 )

The most severely infected field was observed at Pirsabaq, where the percent infection was $66.66 \%$ (bottle 
Table 4 - Incidence of CGMMV in different crops of the plain areas of KPK.

\begin{tabular}{|c|c|c|c|c|}
\hline \multirow[t]{2}{*}{ Crop } & \multicolumn{2}{|c|}{$1^{\text {st }}$ year } & \multicolumn{2}{|c|}{$2^{\text {nd }}$ year } \\
\hline & $1^{\text {st }}$ survey & $2^{\text {nd }}$ survey & $1^{\text {st }}$ survey & $2^{\text {nd }}$ survey \\
\hline Bottle gourd & 25.80 & 59.34 & 24.1 & 49.6 \\
\hline Sponge gourd & 14.95 & 29.95 & 19 & 41.6 \\
\hline Cucumber & 17.90 & 41.65 & 19.9 & 42.3 \\
\hline Squash & 19.55 & 56.33 & 23.1 & 47.3 \\
\hline Pumpkin & 35.65 & 54.46 & 26.3 & 52.9 \\
\hline Melon & 24.95 & 45.51 & 21.3 & 45.1 \\
\hline
\end{tabular}

Table 5 - Incidence of CGMMV in different crops of the northern hilly areas of KPK.

\begin{tabular}{lcc}
\hline Crop & $1^{\text {st }}$ year & $2^{\text {nd }}$ year \\
\hline Lagenaria & 41.66 & 25.4 \\
Cucumber & 36.66 & 36.9 \\
Pumpkin & 37.1 & 36.4 \\
Luffa & 26.6 & 33.5 \\
Squash & 0 & 15.3 \\
\hline
\end{tabular}

gourd) during the second survey of the first season (Table 2). CGMMV has been reported as the most prevalent virus besides other diseases in cucurbits in many cucurbit growing areas (Yuki et al., 2000; Nameth et al., 1986). The farmers of the plain as well as the northern hilly areas had a little or no knowledge about viral diseases as well as their mode of transmission and spread. During our survey of the cucurbit growing areas of KPK it was observed that majority of the farmers used uncertified seeds available in the open market. These seeds have neither been given any treatment, nor are they tested for the presence of seed transmitted viruses, especially CGMMV and CMV. The contact transmission of the CGMMV coupled with the poor phytosanitary measures, the connecting irrigation channels among the fields and use of contaminated tools exacerbate the situation. High population of weed was found in the fields of district Swabi and Charsada which may serve as alternate hosts of the virus. Also, at the early stage of crop growth most of the cucurbit fields were surrounded by crops like maize, tomato, chilies and tobacco and such a cropping pattern in the area also favours the build-up of virus inoculum. Egg plants, tomato, okra and a number of weed plants are the potential reservoirs of CGMMV which contribute to a great extent for the high incidence of viral diseases (Guerini and Murphy, 1999).

\section{Molecular characterization of CGMMV}

RT-PCR results revealed the presence of CGMMV in all the samples collected from areas like Tarujaba, Budni, Jehangira, Serdheri, Swat and Chakdara. Using CG-F and CG-R primers, we were able to amplify an expected band of approximately $1 \mathrm{~kb}$ comprising the full coat protein and partial movement protein region (Figure 1).

The nt (nucleotide) and deduced aa (amino acid) sequences for the CP gene of the three CGMMV isolates when compared with other reported isolates showed very low diversity. All the three isolates showed 100\% amino acid sequence identity among themselves. The aa identities of CGMMV-pk isolates with the isolates reported in the GenBank

http://www.ncbi.nlm.nih.gov/sites/entrez?db=Protein) were in range of $98.052 \%$ (Korea, India and Greece) to 99.351\% (Japan, France, Korea, China, Indonesia and India). CGMMV-pk showed $98.01 \%$ aa identity with the GR7 strain reported from Greece. The amino acid sequence was highly conserved when aligned in the coat protein region sharing high aa sequence identity with a difference of only two amino acids at position 2 and 13 in N-terminal region of coat protein sequence and 5 amino acids in core coat protein region in between amino acid number 64 to 125 (data not shown). Isolates of CGMMV in particular and tobamoviruses in general are very much conserved and show very little variability (Yoon et al., 2008).

The phylogenetic tree based on $\mathrm{CP}$ gene sequence of CGMMV with the other reported sequences resulted in two clusters. All the CGMMV isolates were clustered in a single group (Cluster B). This cluster contains isolates reported from Korea, India, Japan, France, Indonesia, Russia and Greece (Figure 2). Lack of variability in the genome of all these isolates indicates that most of these isolates might have originated from common ancestors or they may be a single strain with recent spread and/or result of high negative selection pressure on CGMMV genome. These results are in agreement with the findings of Yoon et al. (2008) who also reported no remarkable diversity among the reported isolates of CGMMV across the world.

Yodo strain and strain-C (reported from Japan) showed high variability and clustered independently, however they were close to each other in the tree (Cluster A; Figure 2). These two isolates were previously grouped as CGMMV but now they are classified as an independent genus and were renamed as Kuyri Green Mottle Mosaic Virus (KGMMV). This first ever detailed survey of CGMMV in cucurbit growing areas of the KPK province clearly reflects 


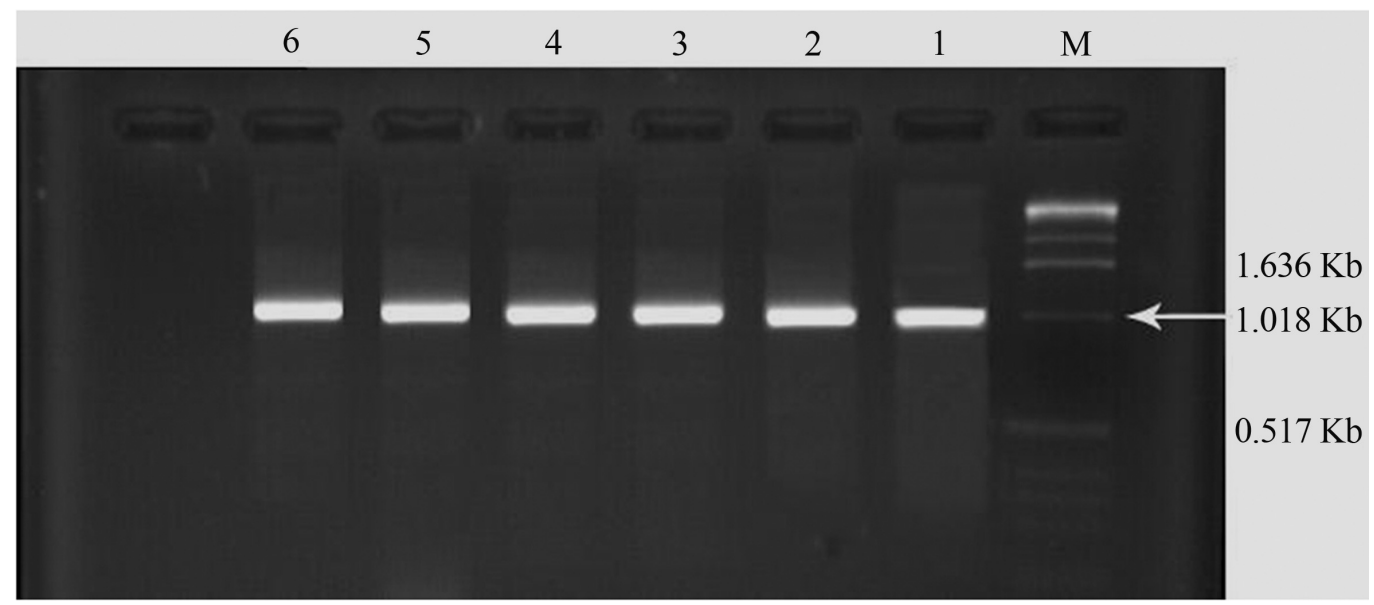

Figure 1 - Agarose (2\%) sho-wing the amplified bands of app: $1 \mathrm{~kb}$ encoding coat proteinand partial movement protein region in the genome of CGMMV. $(1=$ Tarujaba, $2=$ Budni, $3=$ Jehangira, $4=$ Serdheri, $5=$ Swat and $6=$ Chakdara $)$.

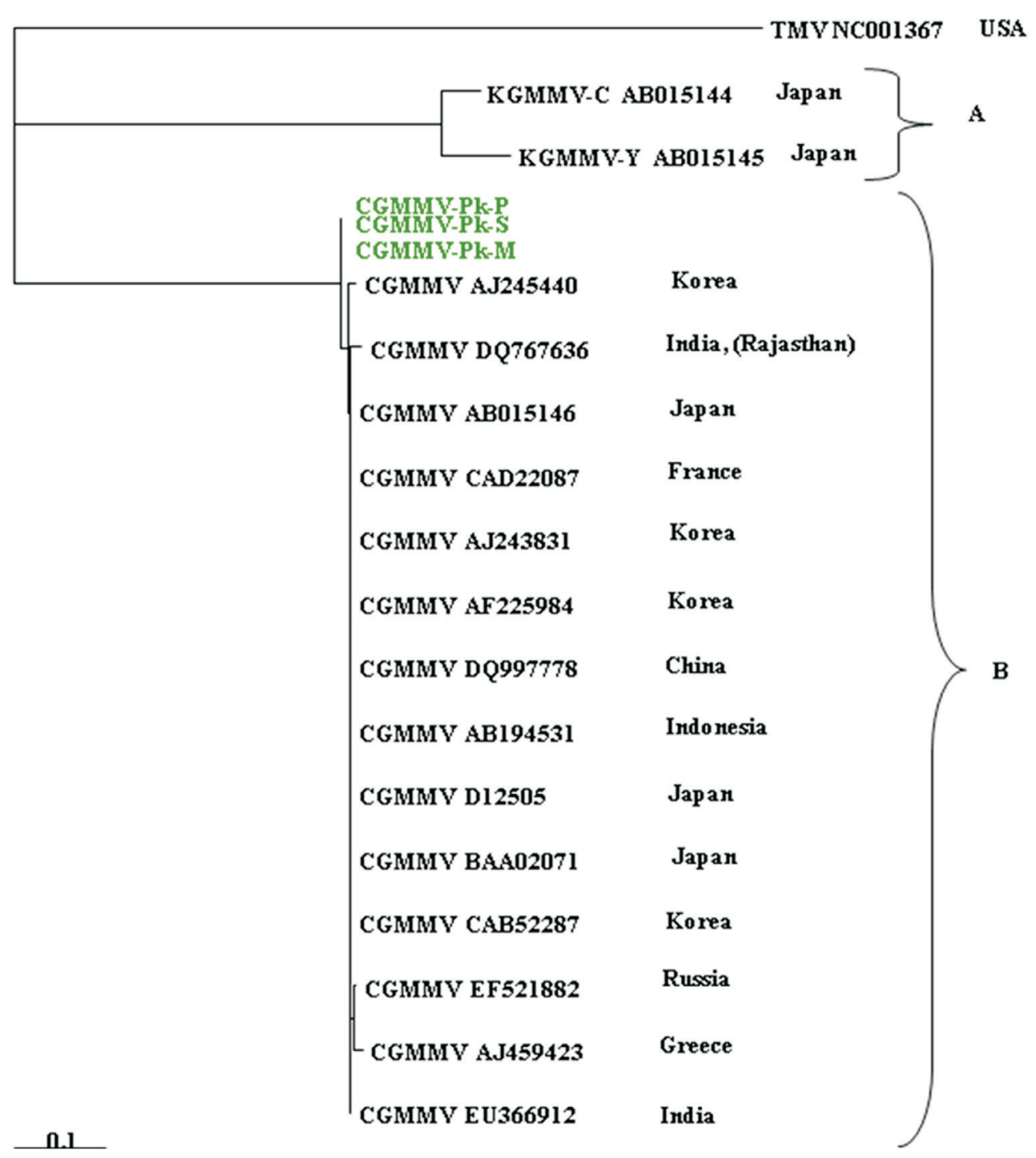

Figure 2 - The phylogenetic relationship of CGMMV isolates reported in the GenBank with Pakistani isolate based on nucleotide sequence of coat protein encoding region using neighbour joining method with a boot strap value of 1000. CGMMV-Pk-S (Swat Isolate; Accession \# AB872115), CGMMV-Pk-P (Peshawar Isolate; Accession \# AB872114), CGMMV-Pk-M (Mardan Isolate; Accession \# AB872113). 
the alarming situation, with such a high prevalence of the virus in almost all the districts where cucurbits are grown, and it further emphasizes the need of implementing a quick and effective integrated control management to bring this menace under control.

\section{References}

Ali A, Natsuaki T, Okuda S (2004) Identification and molecular characterization of viruses infecting cucurbits in Pakistan. J Phytopathol 152:677-682.

Choi GS (2001) Occurrence of two tobamovirus diseases on cucurbits and control measures in Korea. Pl Pathol J 17:243248.

Clark MF, Adams AN (1977) Characteristics of the microplate method of the enzyme-linked immunosorbent assay for the detection of plant viruses. J Gen Virol 34:475-483.

Coutts BA, Jones RAC (2005) Incidence and distribution of viruses infecting cucurbit crops in the Northern territory and Western Australia. Australian. J Agricultural Research 56:847-858.

Desbiez C, Lecoq H (1997) Zucchini yellow mosaic virus. Plant Pathol J 46:809-829.

Guerini MN, Murphy JF (1999) Resistance of Capsicum annum 'Avelar' to Pepper mottle potyvirus and alleviation of this resistance by co-infection with Cucumber mosaic cucumovirus are associated with virus movement. J Gen Virol 80:2785-2792.

Khalid S, Ahmad I (1997) Occurrence of Zucchini yellow mosaic virus (ZYMV) in Pakistan. Int. Conf. Integ. Plant Dis. Manag. For sustainable Agric. Nov. 10-15. New Delhi, India.

Lecoq H, Desbiez C, Wipf-Scheibel, C, Girard M (2003) Potential involvement of melon fruit in the long distance dissemination of cucurbit potyviruses. Plant Dis 87:955-959.

Lecoq H, Dafalla G, Desbiez C, Wipf-Scheibel C, Delecolle B, Lanina T, Ullah, Z, Grumet R (2001) Biological and molec- ular characterization of Morrocan watermelon mosaic virus and a potyvirus isolate from eastern Sudan. Plant Dis 85:547-552.

Lovisolo O (1980) Virus and viroid diseases of cucurbits. Acta Hort 88:33-71.

MINFAL. 2008. Agric. Statistics of Pakistan. Ministry of Food, Agric. and Livest. (Econ. Wing), Islamabad.

Nameth ST, Dodds JA, Paulus AO, Laemmlen FF (1986) Cucurbit viruses of California: An ever-changing problem. Plant Dis 70:8-11.

Provvidenti R (1996) Diseases caused by viruses. In: Zitter TA, Hopkins DL, Thomas CE. (eds) Compendium of Cucurbit Diseases. APS Press, St. Paul, pp 37-45.

Sambrook J, Russell DW (2001) Molecular Cloning: A Laboratory Manual. Cold Spring Harbor Laboratory, Cold Spring Harbor.

Suehiro N, Matsuda K, Okuda S, Natsuaki T (2005) A simplified method for obtaining plant viral RNA for RT-PCR. J.Virol. Methods 125:67-73.

Thompson JD, Higgins DG, Gibson TJ (1994) CLUSTAL W: improving the sensitivity of progressive multiple sequence alignment through sequence weighting, position-specific gap penalties and weight matrix choice. Nucleic Acids Res 22:4673-4680.

Ullman DE, Cho JJ, German TL (1991) Occurrence and distribution of cucurbit viruses in the Hawaiian Islands. Plant Dis 75:367-370.

Yoon JY, Choi GS, Choi SK, Hong JS, Choi JK, Kim W, Lee GP, Ryu KH (2008) Molecular and Biological Diversities of $\mathrm{Cu}$ cumber green mottle mosaic virus from Cucurbitaceous Crops in Korea. J Phytopathol 156:408-412.

Yuki VA, Rezende JAM, Kitajima EW, Barroso PAV, Kuniyuki H, Groppo GA, Pavan MA (2000) Occurrence, distribution, and relative incidence of five viruses infecting cucurbits in the state of Sao Paulo, Brazil. Plant Dis 84:516-520.

All the content of the journal, except where otherwise noted, is licensed under a Creative Commons License CC BY-NC. 